\title{
Significant Factors Affecting Civil Engineering Project Performance
}

\author{
Wan Norizan Wan Ismail ${ }^{1}$, Hamimah Adnan ${ }^{1}$, Ahmad Arzlee Hassan ${ }^{1}$, Noor Aisyah Asyikin Mahat ${ }^{1}$ and Har Einur Azrin \\ Baharuddin $^{1}$
}

${ }^{1}$ Faculty of Architecture, Planning and Surveying, Universiti Teknologi MARA (UiTM), 40450, Shah Alam, Selangor

\begin{abstract}
Civil engineering projects trigger the economic growth by providing infrastructure facilities and job opportunities as well as attracting the attention of foreign investments. Due to their significant contributions toward the nation growth, the performance of civil engineering projects has become the upmost concern by the government. Unfortunately, many civil engineering projects in Malaysia are dominantly associated with unsatisfactory performance in terms of cost, time and quality of the delivered products. Therefore, this paper aims to identify the underlying causes which lead to unsatisfactory performance by determining the factors affecting civil engineering projects. The objective of this paper is to identify the civil engineering project characteristics and the quality of Standard Form of Contract (SFoC) adopted and the contractual behaviour of key participants of civil engineering project which affecting the performance. Questionnaires survey were conducted to undertake the research. 124 feedbacks received out of 300 questionnaires distributed to the G7 contractors registered under Construction Industry Development Board (CIDB) and consultant engineer registered under Board of Engineers Malaysia (BEM). The data was statistically analysed using SPSS 21 and descriptive analysis was used for rank assessment of factors. It was found that the top three (3) most significant factors affecting civil engineering project performance are delay in making payment, environment uncertainty and the clarity of SFoC. These factors belong to three categories i.e the contractual behaviour of key participants, project characteristics and the quality of SFoC category. Thus, these categories are paramount to be put more concern on the performance of civil engineering projects in Malaysia.
\end{abstract}

\section{Introduction}

Civil engineering structures are undeniable important to a nation. Other than facilitating the human daily businesses, the civil engineering structures such as roads, highways, dams, bridges, airports, ports serve the country's development by underpinning the economic and linking social activities. Realizing the important roles of civil engineering structures towards the growth of the nation, the delivery of project on time and satisfactory quality within a reasonable cost become the expectation of the public. Due to the tax payers' money used to finance the civil engineering projects in Malaysia, thus the performance of civil engineering projects become the concern of the government.

Most of studies found in literature focused on the performance of building projects such as studies by [1], [2], [3], [4], and many more. Nevertheless, on the aspect of performance of civil engineering project, there are only few studies have explored in this area for instance [5], [6], [7] and [8]. However, the aforementioned studies only explored on the specific angles on the civil engineering project performance, but do not established a holistic measurement attributes which to be used to measure the project performance. Hence, this provides impetus to contribute to study on the performance of civil engineering projects in Malaysia. In literature, the performance of construction projects is discussed mainly focusing on the time, cost and quality [9], [10], and [11] Thus, this study adopted the same performance indicator since these three indicators are universally acceptance as the main performance indicators in all field of studies as well as stated and ranked as the most important indicators for many types of construction projects by many researchers [12], [3], [13] [1] and [14].

Evidence in literature has replete with the relationship between project performance and the project characteristics and the effects of the latter on the former mainly focusing in building projects for instance such as [15], [16] and [17]. Variety of construction project characteristics have been suggested by previous researchers which can affect the performance of construction projects. [18] grouped the characteristics of construction projects into the project, the owner and the design-builder. Meanwhile, [19] identified change orders, experience and resources as among the factors that affect performance. On top of that, [16] identified 17 project characteristics which then were grouped into project environment and project participant. Undeniably, many conclusive evidences in literature which show that

* Corresponding author: mimad856@gmail.com 
most construction project performance influenced by the characteristics of the construction project. Unfortunately, there is lack of studies can be found in literature which attempt to determine the characteristics of civil engineering project that affect the performance as much as studies focusing on building projects.

On the other hand, the quality of the Standard Form of Contract (SFoC) used for the civil engineering project also found to be among the factors that influenced the project performance. Despite of not many studies discussed on the SFoC adopted in a construction project has direct impacts on performance, the influence of contractual issues towards project performance cannot simply be ignored. In Malaysian construction industry, the common SFoC adopted for civil engineering projects is PWD 203A especially for government projects. However, other types of SFoC such IEM, FIDIC (Red Book and Yellow Book) also have been adopted especially for private projects and the project which involve international participations. Since the contract is the critical governance of the project, the issue such as lack of clarity, fairness and the level of trust produced by the SFoC will adversely affect the relationship between the contracted parties by making it more adversarial and eventually lead to disputes and trigger undesirable behavior of the project participants for instance opportunistic behavior [20], [21], [22], [23] and [24]. Eventually, affects the project performance.

R. Rameezdee et al [25] found that most of the problems in construction projects were related to the contractual behavior of individual key participants in the project. The contractual behavior of the key participants i.e delay in paying interim payment, late in giving possession, architect's behavior, adversarial relationship, poor communication are among other things that affect the project performance [26], [27], [28] and [29]. Unfortunately, none of the study done by the aforementioned authors differentiates by the types of project and mostly focus on the general building projects. None of them focusing on civil engineering projects. Thus, the contractual behavior of the key participants viewed by many previous researchers as important factors that affect project performance. Therefore, the objectives of the study were to identify the characteristics of civil engineering project and the quality of SFoC adopted in civil engineering project and the contractual behavior among the key participants and determine how significant they affect the project performance.

\section{Literature review}

\subsection{Civil engineering project performance criteria}

Basically, time, cost and quality are the common performance variables and have been extensively used for decades in determining the construction project performance. These dimensions which is called 'The Iron Triangle' concept up to this moment are still considered as the central to measuring project performance [30]. By using this 'The Iron Triangle' concept, the construction projects generally considered as successful once they meet those criteria. Due to no performance criteria concept specifically meant for determining the civil engineering project performance, therefore, the performance criteria that considered in this study were cost variance, time variance and quality of workmanship.

Cost variance is referred as the extent to which the planned cost corresponds to the actual cost. Cost overrun might incur if the actual costs are exceeded than the planned cost. Prevalently, in civil engineering project cost overrun is predominant as opposed to under run. In a study on large transportation project in Denmark, [31] concluded that cost overrun of $50-100 \%$ is common for large transportation infrastructure and that overruns above $100 \%$ are not unusual. On the other hand, [32] stated that the total capital cost overrun for United State (US) rail transit projects was calculated $61 \%$. This variance in cost indirectly shows the performance of the projects. On the other hand, [33] highlight that timely completion of a project is frequently seen as a major criterion of project success. [34] in their survey on time performance of large construction projects in Saudi Arabia found that $70 \%$ of the projects experienced time overrun. Similarly does in civil engineering project. A study by [36] on groundwater projects in Ghana indicated that 33 out of 47 projects were delayed. The delay of a civil engineering projects also experiences in other countries such as the UK [36], Thailand [37], Indonesia [19], Lebanon [38], Hong Kong [39], Nigeria [40], [41], Jordan [42] and many more. This shows that delay in delivery of civil engineering project is the indicator of bad performance of civil engineering projects.

Other than the cost and time aspects, [43] found that quality is perceived by the client as the main concerned over time and cost in construction projects, suggesting that the client may be well prepared to sacrifice construction time to improve quality. Quality means producing a product or service that is of a high standard and is fit for purpose. In short, meaning that it does what is supposed to do. As found in literature, many researchers have used the quality of workmanship as one of the indicator in determining the performance of a construction project for instance [45] and [14]. Therefore, the quality of workmanship is considered as one of the important variables in measuring the performance of civil engineering projects.

\subsection{Positioning}

[46], [47] and [15] are among the researchers have explored and identified the characteristics of different types of construction projects. For general building project, [46] explain the project characteristics based on a precise cost estimate before contract signing; time reductions; tight project milestones or deadlines; cost savings; project budget; ability to define the project scope; project size; complexity. [48] classifies the characteristics of refurbishment project based on project 
size; building type; procurement system; types of Standard Form of Contract; contractual arrangement; building occupancy; completeness of design when work commenced on site; design changes made by client during construction; ease of access. From the perspectives of civil engineering works, [47] have determine the project characteristics based on contract size; tender type; bid ratio; percentage difference between awarded bid and estimate; extra project cost; number of bidders; size of contractor; project complexity; type of design and supervision; experience of contractors; project regional location. Unfortunately, the focus given only on the characteristics that influence on the time performance. Very few researches can be referred to in order to determine the characteristics of civil engineering project performance. Due to lack of evidence in literature on the characteristics of civil engineering that influence the project performance, this study identified project characteristics variables gained from literature that are appropriate to be utilized to describe the characteristics of civil engineering project. Therefore, this study refined the project characteristics from the aforementioned previous studies and establish nine (9) characteristics of civil engineering project that might influence the project performance i.e project size; procurement system; types of Standard Form of Contract; project complexity; environment uncertainty; completeness of design when work commenced on site; design changes made by client during construction; ease of access; variety of stakeholders.

\subsection{Quality of SFoC adopted in civil engineering project}

SFoC is a printed form of contract containing standard conditions which are applicable to the wide range of project [49]. In the construction industry sector, due to the construction project characteristics is temporary in nature, the SFoC is more preferable to specially drafted contract because they are comprehensive and ready-touse, thus can minimize the time and cost of negotiating contracts [50]. Unfortunately, there are many debatable issues concerning on the quality of the SFoC used in construction project. Many researchers argue on the aspect of SFoC document incompleteness [51], lack of clarity and disregards modern principles of risk allocation [52], trust issues among the contracting parties and many punitive clauses in the SFoC [53] as well as the fairness issues [54], and [55]. Thus, this study investigated the quality of SFoC adopted in civil engineering projects based on the completeness, level of trust produced, clarity and fairness aspects.

\subsection{Contractual Behaviour of Key Participants of Civil Engineering Projects}

Key participants of a construction project will vary based on the types of construction project as well as the size of the construction project. Due to many key participants with their respective organisations involves in a construction project, the need for a contract is paramount to ensure the well integration and cooperation among themselves in implementing the project. Prevalently, instead of the contract lead to project success, many construction projects eventually ended up unsuccessful with variety of conflicts occur among the participants. [6] listed out that supervision too late and slowness in making decisions; slow to give instructions; lack of consultant's experience; incomplete documents; lack of consultant's site staff experience (managerial and supervisory personnel); absence of consultant's site staff; financial problems; shortage of materials on site; poor site management; construction mistakes and defective work; delay in delivery of materials to site; coordination problems with others are among the important causes of problems that will reduce the construction project success in Malaysian context. Not only in Malaysia, the undesired contractual behaviour of key participants also has been argued by many researchers could affect project performance for instance [57] Nigeria, [34] in Saudi, [37] in Thailand, [38] in Lebanon and [39] in Hong Kong. Thus, this study explored the contractual behaviour of key participants in civil engineering project such as usage of SFoC in making decision, unauthorised instruction, obeying the unauthorised instruction, communication skills of engineer and contractor and delay in making payment.

\section{Methodology}

The study focused on civil engineering projects in Malaysia. The focus of research was limited to the roads projects in Malaysia including their associated structures such as bridges and tunnels. A specific area and locality was determined to ensure that the research can be covered within the limited time of study. The data for this study was obtained from G7 of CIDB's listed contractors and certified professional engineers registered under The Boards of Engineers Malaysia (BEM). In addition, to provide better analysis of the project characteristics that influence civil engineering project performance, the study covered civil engineering projects with the contract value of more than RM10 million.

The aim of the study was to explore the effects of civil engineering project characteristics and the quality of SFoC towards performance. In order to achieve it, a quantitative approach using questionnaire was adopted. As shown in Figure 1, this study involved three (3) steps. It was started with an intensive literature review to identify the project performance criteria to be used in this study, the characteristics of civil engineering project and the quality of SFoC which have the possibility in affecting the project performance. Various project characteristics, the quality of SFoC and performance criteria from variety types of construction project were intensively reviewed in order to select the most appropriate variables of project characteristics, the quality of SFoC and performance criteria to be used for the civil engineering project. It was found that nine (9) civil engineering project characteristics i.e project size; procurement system; types of SFoC; project complexity; 
environment uncertainty; completeness of design when work commenced on site; types of design and supervision; ease of access; variety of stakeholders and four (4) quality aspects of SFoC i.e the completeness, level of trust produced, clarity and fairness and five (5)contractual behaviour of key participants i.e the usage of SFoC in making decision, unauthorised instruction, obeying the unauthorised instruction, Communication skills of engineer and contractor and delay in making payment which have possible effect on civil engineering project performance.

Next, to ensure the validity of variables gained from literature reviews, preliminary questionnaire survey was conducted to G7 contractors and consultant engineers. The respondent selected have the criteria for instance, designated in the position of professionals; have current, recent or direct involvement in constructing civil engineering projects particularly in public funding projects; have at least five years' working experience. This phase has formed the foundation for subsequent phase and assisted in the design of the main survey. Ten (12) responses gained by the cut-off date given and then the Realiability Test using a Cronbach's coefficient alpha test was perform. Reliability Test showed internal consistency with value of the test was 0.745 , which was more than 0.7 . This indicates that the 5-point Likert scale measurement was reliable, and the main questionnaire survey could be carried out to all respondents.

Next phase was for the collection of main data for the study. Since this study involved large sample of population, questionnaire survey is appropriate where it requires respondents to answer the same set of questions effectively. The questionnaire survey that employed was expected to accomplish the first three objectives; to identify the criteria in measuring civil engineering project performance; to identify the civil engineering project characteristics; and to identify the quality of SFoC adopted in civil engineering projects. The simple multiple choice and Likert-type of questions was used in collecting data on respondents' opinions on the performance criteria, project characteristics and the quality of $\mathrm{SFoC}$ used civil engineering projects. In responding to the questionnaire, respondents were requested to indicate the level of significance of each of the factors. The level of importance is measured on a 5point Likert scale where 5=Extremely Significant; 4=Very Significant; 3=Moderately Significant; $2=$ Slightly Significant; $1=$ Not Significant. The questionnaires were distributed via e-mail and personal delivery. Out of 300 numbers of questionnaire sent out, only 124 numbers were return before cut of date given representing $41 \%$ response rate. The data gathered was analysed using statistical software SPSS version 21 . Descriptive analysis was deployed to rank the factors.

\section{Result and discussion}

4.1 Civil engineering project performance
criteria

The demographic background of respondents participated in this survey are summarised in Table 1, Table 2 and Table 3.

Table 1. Types of respondent's organisation

\begin{tabular}{|l|c|c|}
\hline \multirow{2}{*}{$\begin{array}{l}\text { Types of } \\
\text { organisation }\end{array}$} & \multicolumn{2}{|c|}{ Respondents } \\
\cline { 2 - 3 } & No & $\%$ \\
\hline Consultant & 57 & $46 \%$ \\
\hline Contractor & 67 & $54 \%$ \\
\hline \multicolumn{1}{|c|}{ Total } & 124 & $100 \%$ \\
\hline
\end{tabular}

Table 2. Respondents' length of experience in civil engineering works

\begin{tabular}{|l|c|c|}
\hline \multirow{2}{*}{$\begin{array}{l}\text { Length of experience } \\
\text { in civil engineering } \\
\text { projects }\end{array}$} & \multicolumn{2}{|c|}{ Respondents } \\
\cline { 2 - 3 } & No & \% \\
\hline$<3$ yrs & & $0 \%$ \\
\hline $3-5$ yrs & 15 & $12 \%$ \\
\hline $5-10 \mathrm{yrs}$ & 57 & $46 \%$ \\
\hline$>10 \mathrm{yrs}$ & 52 & $42 \%$ \\
\hline \multicolumn{1}{|c|}{ Total } & 124 & $100 \%$ \\
\hline
\end{tabular}

Table 3. Respondents' status in their respective organisations

\begin{tabular}{|l|c|c|}
\hline \multirow{2}{*}{\multicolumn{1}{c}{ Position }} & \multicolumn{2}{|c|}{ Respondents } \\
\cline { 2 - 3 } & No & $\%$ \\
\hline CEO/ Director & 0 & $0 \%$ \\
\hline Engineer & 52 & $42 \%$ \\
\hline Quantity Surveyor & 60 & $48 \%$ \\
\hline Supervisor & 2 & $2 \%$ \\
\hline Project manager & 10 & $8 \%$ \\
\hline \multicolumn{1}{|c|}{ Total } & 124 & $100 \%$ \\
\hline
\end{tabular}

As shown in Table 1, Table 2 and Table 3, the respondents of this study consist of $54 \%$ contractors and $46 \%$ consultant with $98 \%$ of their position at their respective organisations are at executive level. Furthermore, the respondents' working experience in civil engineering were $42 \%$ more than 10 years' experience and $46 \%$ have experience between 5 to 10 years. These indicate that the respondents of this study were capable and competent enough to participate in this study.

\section{Ranking the factors affecting civil engineering project performance.}

The ranking assessment was carried out based on level of significant of every factor. The ranking assessment was done by calculating the mean value for overall respondents as tabulated in Table 4 . Table 4 shows the top 3 most significant factors affecting the civil 
engineering project performance were delay in making payment, environment uncertainty and the clarity of SFoC.

\subsection{Delay in making payment}

Delay in making payment was ranks as the most significant factors affecting the performance of civil engineering projects $(\mathrm{M}=4.98)$. As rated by all respondents, delay in making payment is in-lined with findings by many previous researchers who found that this factor is the most influencing factors which can affect construction project performance for instance [58], [3] and [59]. In fact, interim payment can be considered as the 'blood' of the contractor in construction process to maintain the contractor's cash flow and minimising the contractor's cash deficit [60]. In addition, the payment also important to contractor due to high investment made by the contractor at the preliminary stage of construction process. Problems in contractor's cash flow will affect the smoothness of construction process. Thus, delay in paying making payment is the undesired contractual behaviour of the client towards contractor which could give significant impact towards civil engineering project performance.

Table 4. Ranking the factors affecting civil engineering project performance

\begin{tabular}{|l|c|c|c|c|}
\hline $\begin{array}{l}\text { Factors affecting } \\
\text { civil engineering } \\
\text { project } \\
\text { performance }\end{array}$ & $\mathrm{N}$ & Mean & $\begin{array}{c}\text { Std. } \\
\text { Deviation }\end{array}$ & Rank \\
\hline $\begin{array}{l}\text { Delay in making } \\
\text { payment }\end{array}$ & 124 & 4.98 & 0.126 & 1 \\
\hline $\begin{array}{l}\text { Environment } \\
\text { uncertainty }\end{array}$ & 124 & 4.98 & 0.126 & 1 \\
\hline $\begin{array}{l}\text { The clarity of } \\
\text { SFoC }\end{array}$ & 124 & 4.96 & 0.198 & 2 \\
\hline $\begin{array}{l}\text { The fairness of } \\
\text { SFoC }\end{array}$ & 124 & 4.95 & 0.215 & 3 \\
\hline $\begin{array}{l}\text { Construction } \\
\text { complexity }\end{array}$ & 124 & 4.94 & 0.247 & 4 \\
\hline Project type & 124 & 4.9 & 0.308 & 5 \\
\hline $\begin{array}{l}\text { The completeness } \\
\text { of SFoC }\end{array}$ & 124 & 4.89 & 0.318 & 6 \\
\hline $\begin{array}{l}\text { Communication } \\
\text { skills of engineer } \\
\text { and contractor }\end{array}$ & 124 & 4.3 & 0.459 & 7 \\
\hline $\begin{array}{l}\text { Type of standard } \\
\text { form of contract }\end{array}$ & 124 & 4.05 & 0.281 & 8 \\
\hline $\begin{array}{l}\text { Usage of SFoC in } \\
\text { making instruction }\end{array}$ & 124 & 4.03 & 0.177 & 9 \\
\hline $\begin{array}{l}\text { Design } \\
\text { completion before } \\
\text { construction start }\end{array}$ & 124 & 4.03 & 0.177 & 9 \\
\hline $\begin{array}{l}\text { Procurement } \\
\text { method }\end{array}$ & 124 & 4.03 & 0.177 & 9 \\
\hline $\begin{array}{l}\text { Variety of } \\
\text { stakeholders }\end{array}$ & 124 & 3.99 & 0.201 & 10 \\
\hline
\end{tabular}

\begin{tabular}{|l|c|c|c|c|}
$\begin{array}{l}\text { The trust produced } \\
\text { by SFoC }\end{array}$ & 124 & 3.98 & 0.154 & 11 \\
\hline Ease of site access & 124 & 3.94 & 0.247 & 12 \\
\hline $\begin{array}{l}\text { Unauthorised } \\
\text { instruction }\end{array}$ & 124 & 3.94 & 0.247 & 12 \\
\hline $\begin{array}{l}\text { Obeying } \\
\text { unauthorised } \\
\text { instruction }\end{array}$ & 124 & 3.89 & 0.318 & 13 \\
\hline $\begin{array}{l}\text { Type of design } \\
\text { and supervision }\end{array}$ & 124 & 3.77 & 0.42 & 14 \\
\hline
\end{tabular}

\subsection{Environment uncertainty}

Environment uncertainty also was ranked as the most significant factors affecting the civil engineering project performance which shared mean value with delay in making payment $(\mathrm{M}=4.98)$. On other types of construction projects, many researchers argue that uncertainty affects project performance for instance [45] on refurbishment projects, [55] on general building projects. Civil engineering projects are unique. Their natures are very different to that of general building construction where mostly they have to be designed for some specific purposes and specific location before they can be constructed and put into use. This makes, civil engineering projects are the projects that mainly full of uncertainty and most of the time quite complex, difficult to manage and replete with unpredictable behaviour of project key participants. Therefore, environment uncertainty was determined as the most significant factor affecting civil engineering project performance.

\subsection{Clarity of SFoC}

The clarity of SFoC was ranked as the second most affecting factors towards civil engineering project performance $(M=4.96)$. This is very true because the SFoC plays an important role in governing all aspects of civil engineering projects. Therefore, the clarity of SFoC adopted in terms of content, wording and roles of contracting parties are paramount. This is because different interpretation could denote a dispute regarding the contractual obligations and expectation between the contracting parties [61]. [62] argue that ease of language structure and the conciseness of clauses which is free from unnecessary information is important to avoid misinterpretation. According to W. Lu, L. Zhang et al [24], lack of clarity in standard form of contract is mainly attributable to long sentence length, poor layout and the presence of many redundant legal expressions. The same argument also is also shared by other researchers for instance [63], [61] and [64]. Thus, the clarity of SFoC is very important as a good governance in civil engineering projects. Wrong interpretation could lead to dissatisfaction among the contracting parties eventually affects the civil engineering project performance. 


\section{Conclusion}

Civil engineering project performance in Malaysia is considered unsatisfactory where most projects associated with severe cost and time overruns. Therefore, a mitigating action must be put into civil engineering projects to ensure the future civil engineering projects can be delivered within budget, time and quality required. This study attempts to contribute to this mitigating action by identifying the root cause which dominantly affecting the previous civil engineering project performance. Result of this study found that delay in payment, environment uncertainty as well the clarity of SFoC plays in important part affecting civil engineering project performance. Therefore, these three factors must be given more concern by the government and project participants to ensure we can deliver world class civil engineering project for a better Malaysia.

The authors would like to thank the Institute Pengurusan Penyelidikan dan Inovasi (IRMI) UiTM for supporting this research under Geran Penyelidikan Lestari 2015, 600RMI/DANA 5/3/LESTARI (23/2015)

\section{References}

1. A. P. C. Chan and A. P. L. Chan, "Key performance indicators for measuring construction success," Benchmarking An Int. J., vol. 11, no. 2, pp. 203-221, 2004.

2. I. M. Shohet, "Key performance indicators for maintenance of health-care facilities," Facilities, vol. 21, no. 1/2, pp. 5-12, 2003.

3. A. J. Nurul, M. Y. Aminah, I. Syuhaida, and C. S. Chai, "Public construction projects performance in Malaysia," J. Southeast Asian Res., vol. 2016, no. 2016, pp. 1-29, 2016.

4. L. Zhang and W. Fan, "Improving performance of construction projects," Eng. Constr. Archit. Manag., vol. 20, no. 2, pp. 195-207, Feb. 2013.

5. H. Doloi, "Assessing stakeholders 'influence on social performance of infrastructure projects," Facilities, vol. 30, no. 11, pp. 531-550, Aug. 2012.

6. H. Yao, L. Shen, Y. Tan, and J. Hao, "Simulating the impacts of policy scenarios on the sustainability performance of infrastructure projects," Autom. Constr., vol. 20, no. 8, pp. 1060-1069, Dec. 2011.

7. H. Yao, L. Shen, Y. Tan, and J. Hao, "Simulating the impacts of policy scenarios on the sustainability performance of infrastructure projects," Autom. Constr., vol. 20, no. 8, pp. 1060-1069, Dec. 2011.

8. F. Y. Y. Ling, Y. Ke, M. M. Kumaraswamy, M. Asce, and S. Wang, "Key Relational Contracting Practices Affecting Performance of Public
Construction Projects in China," J. Constr. Eng. Manag., vol. 142, no. March, pp. 1-12, 2013.

9. A. Amiril, A. H. Nawawi, R. Takim, S. Nur, and F. Ab, "Transportation Infrastructure Project Sustainability Factors and Performance," Procedia - Soc. Behav. Sci., vol. 153, pp. 9098, 2014.

10. P. Doan and K. Menyah, "Impact of Irreversibility and Uncertainty on the Timing of Infrastructure Projects," J. Constr. Eng. Manag., vol. 139, no. MARCH, pp. 331-338, 2013.

11. C. C. Cantarelli, B. van Wee, E. J. E. Molin, and B. Flyvbjerg, "Different cost performance: different determinants?," Transp. Policy, vol. 22, pp. 88-95, Jul. 2012.

12. S. Verweij, I. van Meerkerk, and I. a. Korthagen, "Reasons for contract changes in implementing Dutch transportation infrastructure projects: An empirical exploration," Transp. Policy, vol. 37, pp. 195202, Jan. 2015.

13. K. C. Iyer and K. N. Jha, "Factors affecting cost performance: Evidence from Indian construction projects," Int. J. Proj. Manag., vol. 23, no. 4, pp. 283-295, 2005.

14. R. Takim and A. Akintoye, "Performance Indicators for Successful Construction Project Performance," Assoc. Res. Constr. Manag., vol. 2, no. September, pp. 2-4, 2002.

15. M. A. N. Masrom, M. H. I. A. Rahim, S. Mohamed, G. K. Chen, and R. Yunus, "Successful Criteria for Large Infrastructure Projects in Malaysia," Procedia Eng., vol. 125, no. September, pp. 143-149, 2015.

16. S. Demirkesen and B. Ozorhon, "Assessing the Impact of Project Characteristics on Construction Project Success," 12th Int. Congr. Adv. Civ. Eng. ACE2016., pp. 1-8, 2016.

17. K. Cho, T. Hong, and C. Hyun, "Effect of project characteristics on project performance in construction projects based on structural equation model," Expert Syst. Appl., vol. 36, no. 7, pp. 10461-10470, 2009.

18. A. Shah Ali, S. Nizam Kamaruzzaman, and $\mathrm{H}$. Salleh, "The characteristics of refurbishment projects in Malaysia," Facilities, vol. 27, no. 1/2, pp. 56-65, 2009.

19. Molenaar, Keith \& D. Songer, Anthony. (1998). Model for Public Sector Design-Build Project Selection. Journal of Construction Engineering and Management. $124 . \quad 467-479$. 10.1061/(ASCE)0733-9364(1998)124:6(467).

20. Kaming, P.F., Olomolaiye, P.O., Holt, G.D. and Harris, F. (1997), "Factors influencing construction time and cost overruns on highrise projects in Indonesia", Construction Management and Economics, Vol. 15, pp. 8394. 
21. Williamson, O.E., 1985. The Economic Institutions of Capitalism: Firms, Markets, Relational Contracting. Free Press, New York.

22. Bresnen, M. and Marshall, N. (2000), "Motivation, commitment and the use of incentives in partnerships and alliances", Construction Management and Economics, Vol. 18, pp. 587-98.

23. S. O. Cheung and T. W. Yiu, "Are construction disputes inevitable?," IEEE Trans. Eng. Manag., vol. 53, no. 3, pp. 456-470, 2006.

24. W. Lu, L. Zhang, and L. Zhang, "Effect of Contract Completeness on Contractors' Opportunistic Behavior and the Moderating Role of Interdependence," J. Constr. Eng. Manag., vol. 142, no. 6, p. 4016004, 2016.

25. R. Rameezdeen and A. Rodrigo, "Modifications to standard forms of contract: The impact on readability," Australas. J. Constr. Econ. Build., vol. 14, no. 2, pp. 31-40, 2014.

26. S. Toor and S. O. Ogunlana, "Construction professionals' perception of critical success factors for large-scale construction projects," Constr. Innov., vol. 9, no. 2, pp. 149-167, Apr. 2009.

27. N. Jaffar, a. H. A. Tharim, and M. N. Shuib, "Factors of Conflict in Construction Industry: A Literature Review," Procedia Eng., vol. 20, pp. 193-202, 2011.

28. M. Sambasivan and Y. W. Soon, "Causes and effects of delays in Malaysian construction industry," Int. J. Proj. Manag., vol. 25, no. 5, pp. 517-526, 2007.

29. A. R. Chini and H. E. Valdez, "ISO 9000 and the U . S . Construction Industry," J. Manag. Eng., vol. 19, no. 2, pp. 69-77, 2003.

30. Ling, F. Y. Y., Ke, Y., Kumaraswamy, M. M., Asce, M., \& Wang, S. (2013). Key Relational Contracting Practices Affecting Performance of Public Construction Projects in China. Journal of Construction Engineering and Management, 142(March), $1-12$. https://doi.org/10.1061/(ASCE)CO.1943-7862

31. K. E. Papke-Shields, C. Beise, and J. Quan, "Do project managers practice what they preach, and does it matter to project success?," Int. J. Proj. Manag., vol. 28, no. 7, pp. 650-662, Oct. 2010.

32. Skamris, M.K., Flybjerg, B., 1997. Inaccuracy of traffic forecasts and cost estimates on large transport projects. Transport policy 4 (3), 11146.

33. Pickrell, D.H., 1990. Urban rail transit projects: forecasts versus actual ridership and cost. US Department of Transportation, Washing ton

34. Rwelamila, P.D. and Hall, K.A. (1995), "Total systems intervention: an integrated approach to time, cost and quality management", Construction Management and Economics, Vol.
13, pp. 235-41.

35. Assaf, S.A. \& Al-Hejji, S. (2006). Causes of delay in large construction projects International Journal of Project Management, 24, 349-357.

36. Frimpong, Y., Oluwoye, J. and Crawford, L. (2003), "Causes of delay and cost overruns in construction of groundwater projects in a developing countries: Ghana as a case study", International Journal of Project Management, Vol. 21, pp. 321-6.

37. Nkado, R.N. (1995), "Construction timeinfluencing factors: the contractor's perspective", Construction Management and Economic, Vol. 13, pp. 81-9.

38. Mezher, T. and Tawil, W. (1998), "Causes of delays in the construction industry in Lebanon", Engineering, Construction and Architectural Management, Vol. 5 No. 3, pp. 252-60.

39. Okpala, D.C. and Aniekwu, A.N. (1988), "Causes of high costs of construction in Nigeria", Journal of Construction Engineering and Management, Vol. 114 No. 2, pp. 233-44.

40. Elinwa, A.U. and Joshua, M. (2001), "Timeoverruns factors in Nigerian construction industry", Journal of Construction Engineering and Management, Vol. 127 No. 5, pp. 419-25.

41. Al-Momani, A.H. (2000). Examining service quality within construction processes, Journal of Technovation, 20, 643-651.

42. Bowen, P.A., Cattel, K.S., Hall, K.A, Edwards, P.J. \& Pearl, R.G. (2002). Perceptions of time, cost and quality management on building projects, Australian Journal of Construction Economics and Building, 2(2), 48-56.

43. I. Rahmat and A. S. Ali, "The involvement of the key participants in the production of project plans and the planning performance of refurbishment projects," J. Build. Apprais., vol. 5, no. 3, pp. 273-288, 2010.

44. B. Liu, T. Huo, Y. Liang, Y. Sun, and X. Hu, "Key Factors of Project Characteristics Affecting Project Delivery System Decision Making in the Chinese Construction Industry: Case Study Using Chinese Data Based on Rough Set Theory," J. Prof. Issues Eng. Educ. Pract., vol. 137, no. January, pp. 206-210, 2012.

45. A. A. Othman, J. V. Torrance, and M. A. Hamid, "Factors influencing the construction time of civil engineering projects in Malaysia," Eng. Constr. Archit. Manag., vol. 13, no. 5, pp. 481501, 2006.

46. Pena-Mora, F, Sosa, C.E. \& McCone, D.S. (2003). Introduction to construction dispute resolution. New Jersey: Prentice Hall.

47. M. Chan, Y. Li, and H. Besar, "New Engineering Contract ( Nec ) 1993 As Radical Changes To the Malaysian Standard Forms of Contract, Unpublished Master Tesis ," Univ. Teknol. 
Malaysia, 2006.

48. Harban Singh, K.S. (2011). The PAM Contract 2006: An overview professional \& the JKR Forms (Rev. 2007). 1-day Seminar, Board of Quantity Surveyors Malaysia, March 2011.

49. W. Hughes et al., "Construction contract policy: do we mean what we say?," RICS Found. Res. Pap. Ser., vol. 4, no. 12, 2002.

50. X. H. Jin and G. Zhang, "Modelling optimal risk allocation in PPP projects using artificial neural networks," Int. J. Proj. Manag., vol. 29, no. 5, pp. 591-603, 2011.

51. F. Nasirzadeh, M. Khanzadi, and M. Rezaie, "Dynamic modeling of the quantitative risk allocation in construction projects," Int. J. Proj. Manag., vol. 32, no. 3, pp. 442-451, 2014.

52. W. Alaghbari, M. Razali A. Kadir, A. Salim, and Ernawati, "The significant factors causing delay of building construction projects in Malaysia," Eng. Constr. Archit. Manag., vol. 14, no. 2, pp. 192-206, 2007.

53. I. El-adaway, S. Fawzy, H. Burrell, and N. Akroush, "Studying Payment Provisions under National and International Standard Forms of Contracts," J. Leg. Aff. Disput. Resolut. Eng. Constr., no. July, p. 4516011, 2016.

54. H. Adnan, N. Hashim, N. Mohd, Yusuwan, and N. Ahmad, "Ethical Issues in the Construction Industry: Contractor's Perspective," Procedia Soc. Behav. Sci., vol. 35, no. December 2011, pp. 719-727, 2012.

55. L. Guo, H. Li, P. Li, and C. Zhang, "Transaction costs in construction projects under uncertainty," Kybernetes, vol. 45, no. 6, pp. 866-883, Jun. 2016.

56. H. Y. Chong and R. M. Zin, "A case study into the language structure of construction standard form in Malaysia," Int. J. Proj. Manag., vol. 28, no. 6, pp. 601-608, 2010.

57. A. A. Bubshait and S. A. Almohawis, "Evaluating the general conditions of a construction contract," Int. J. Proj. Manag., vol. 12, no. 3, pp. 133-136, 1994.

58. N. A. N. A. Ali and S. Wilkinson, "Modernising construction contract drafting - A plea for good sense," Proc. 18th CIB World Build. Congr., pp. 323-345, 2010.

59. J. N. Wright and W. Fergusson, "Benefits of the NEC ECC form of contract: A New Zealand case study," Int. J. Proj. Manag., vol. 27, no. 3, pp. 243-249, 2009. 